\title{
Utak, kereszteződések, csomópontok
}

\section{Ugrai János}

Eszterházy Károly Egyetem Pedagógiai Karának egyetemi docense ugraij@gmail.com

DOI: 10.37205/TEL-hun.2020.3-4.04

átfogó megközelités - konkrét program hatása - sokszínü hallgatóság - üzenet kompetencia - képzés hatása a kompetenciára - közösségi tanulás - sokszínü tanulási környezet - mentorálás - a mentorálás személyes szintje - érzelmi intelligencia mozgósítása - bizalmi kapcsolat a mentor és a mentorált között - reflexiós szakasz - önszabályozás - éntudatosság - motiváció - kihívásokra adott válasz - pozitív énkép - pozitív pszichológiai tőke - partnerség

intézményi sajátosságok - elvárásrendszerek (KKK, felvevő piac) - diverzív szervezeti szocializációs minta - hátrányos helyzet - periférikusság - rekrutációs bázis - első generációs értelmiségi - reziliencia - család-vallás-hivatásetika - a régióban maradás - másfajta szocializációs minta megtapasztalásának korlátozottsága - „,kinyitni” a hallgatót az értékek, a magas kultúra felé - a saját és a remélt szint közötti különbség megugrásának nehézségei - hallgatói klaszter - pedagógiai érték

szakmai fejlődés - szakpolitika - nem formalizált vagy önszabályozó tanulás - egyéni tanulás - kontextualitás - makro-, mezo- és egyéni szint - változás - rendszerszervezet - hallgatói nézőpont - tagok által érzékelt terek - szakmai közösség - humánökológiai nézőpont - személyes nézőpont - személyesség - dilemma

fejlesztés - kognitív készségek - kutatásalapú gyakorlat - intenzív reflexió - visszacsatolás - tanulságok másokkal való megosztása - bemeneti mérés - problémamegoldó gondolkodás - interakció a rendszerrel - a rendszer eljuttatása a célállapotba induktív gondolkodás - akciókutatások - hatékonyságnövelés - lassan bővülö fogalomértelmezések - tapasztalat - a tapasztalat ereje - tantárgypedagógiai kutatások - jó gyakorlatok nemzetközi térben is - komplex hatásrendszer - lassú folyamat

Hazánk négy tudományegyetemi tanárképző és pedagóguskutató (pedagógusképzés-kutató) műhelyének közös bemutatkozó szimpóziumán az egyes előadások 
során ezek voltak a lejegyzésre leginkább kívánkozó kulcskifejezések. Nem tudom, mennyire kell ahhoz e szakmában bennfentesnek lenni, hogy csalhatatlanul társítsuk a fogalomsorokhoz az adott tanárképző műhelyt: Debrecent, Pécset, Szegedet és az ELTE-t.

Magam legfeljebb félig számíthatok bennfentesnek. Közel két évtizede dolgozom a tanárképzésben, hét-nyolc éven át aktív szervező-vezető munkakörben dolgoztam egy sokkal kisebb, bár - legalább egy ideig akkor még - nem kevésbé markáns tanárképző mühelyben, Miskolcon, s most is egy nagy pedagógusképző intézményben, s annak pedagóguskutatással kiemelten foglalkozó doktori iskolájában is tevékenykedem. Ám sem a tanárképzés, sem a pedagóguskutatás terén nem veszek részt a napi szakmai tudományos diskurzusban, elsődleges kutatási területem viszonylag távol áll ettől a világtól. E sajátos, félig outsider, félig bennfentes pozícióból megítélve úgy látom, hogy sem utólag nem okozna semmilyen nehézséget intézménynévvel társítani a fenti bekezdéseket, sem előzetesen nem tévedtem volna különösebben nagyot, ha a programban szereplő előadásokhoz nekem kellett volna jellemző kulcsfogalmakat megelőlegeznem.

Ezt én komoly értéknek tekintem. Olyan kijegecesedett, évtizedes hagyományokból táplálkozó domináns megközelítési módok, narratívák mentén körvonalazódnak a legfőbb tanárképző mühelyeink tevékenységei, amelyek messziről is pontosan beazonosíthatók. Probléma-meghatározásban, nyelvhasználatban, de még az egyéb nyelvi eszközökben is (hangsúly, hanghordozás, a legjellemzőbb szavak, kifejezések ismétlése stb.) megnyilvánul az, hogy az ország különböző pontjain a tanárképzés különböző jelenségekre és összefüggésekre fókuszál. Az is biztató, örömteli tapasztalás lehetett a szimpózium hallgatóságának, hogy szinte minden műhely részéről egynél többen szólaltak meg az előadások után, a vitában - és a helyi nyelvezet a szereplőváltástól függetlenül nem változott.

Az egyedi sajátosságok számos tényező mentén megragadhatóak, az érintett intézmények és szervezeti egységek, azok történeti sajátosságai, a szakmai mühelyek személyi összetétele legalább annyira meghatározzák azt a pályát, amin lehetőségük van mozogni, mint az intézmények, szervezeti egységek közvetlen környezete, annak szociokulturális jellegzetességei. Nyilvánvalóan mást jelent a magyar kultúra egész fejlődésének tükrében, ha azt mondom, hogy Debrecen, vagy ha azt, hogy Pécs. Másként lehet Budapestről szemlélni a világot, mint Baranya szellemi centrumából. Bizonyosan más érzelmi és szellemi energiák lépnek működésbe, ha a Kiss Árpád Emlékszobában ül össze egy új munkaterv kidolgozására 
egy közösség, mint amikor Nagy József örökségének jegyében gondolkodnak a kutatók - és a sort akár tetszőleges ideig folytathatnánk.

Az élesen körvonalazódó különbségek talán egy olyan szójátékkal illusztrálhatók, amelyben több az igazság, mint az erőltetettség. Csaknem minden előadásban deklaráltan el is hangzott, s tényleg minden előadás az értékekről, a társadalmi értékek pedagógiai munkába emeléséről szólt, mégis mindig másként: Arató Ferenc Pécsről hosszan beszélt arról az értékfeltáró tevékenységről, amelynek keretében tanárjelölt hallgatók egyetemi oktatók szoros támogatásával vidéki, rossz szociokulturális státusú iskolákba mennek ki megízlelni az iskolai mindennapok kevésbé napos (vagy legalábbis: kevésbé naposnak tűnő) oldalát, s eközben friss levegőt visznek ezekbe a csaknem teljesen reménytelen helyzetbe süllyedt közösségekbe. Értékek feltárásaként értelmezem ezt a programot, hiszen a tanárjelölt hallgató olyat tapasztal meg magából, szakmai és emberi érzékenységéből, tettrekészségéből, aminek a birtoklásával kapcsolatban egyáltalán nem biztos, hogy tisztában van - s amelynek a megtapasztalása egész életére meghatározó hatással lehet. Az egyetemi polgárok nem pusztán „megjelennek falun”, hanem huzamosabb ideig részesei és alakítói lesznek a zsákutcás települések iskolai mindennapjainak. Talán épp valamelyikőjük lesz az a Valaki, aki majd minden reziliens tanuló élettörténetében megbújik mint ösztönző, támogató, a kiemelkedést segítő referenciaszemély. A mentorprogram - ha jól csinálják - nemcsak a tanárjelöltben vagy a többre-jobbra hivatott tanulóban találja meg a kiaknázható értékeket, hanem a bajba jutott kis iskola pedagógus közösségében is. Esély nyílik az épp a kiégés szélén egyensúlyozó, ám igazán jóérzésű és szakmailag is tudatos, innovációk iránt esetleg fogékony, az együttműködésre hajlandó pedagógusok megtalálására, megszólítására, hálózatépítésre, szakmai közösség kialakítására - jó emberekből.

Értékek bemutatása, megismertetése, s ezáltal értékek védelme került előtérbe Chrappán Magdolna előadásában. A cél a már egyetemre eljutott, zömében a baranyaihoz eléggé hasonló hátterủ hallgatók bevezetése abba a világba, amelyben az eligazodás egy értelmiségitől, egy leendő tanárembertől feltétlenül elvárható jóllehet az illető klasszikus első generációs értelmiségi lesz a végzés után. A hallgató „kinyitása” (akkor is, ha éppen testnevelés szakos), színház-, hangversenylátogatásának ösztönzése legalább olyan fontos eleme a lemorzsolódás megakadályozásának, mint a pedagógusképzés szűken értelmezett KKK-jának regionális sajátosságok szerinti értelmezése. A debreceni tanárképzés mögött álló népes kutatócsoport jó ideje vizsgálja, értelmezi a rezilienciának, a legkülönbözőbb sajátos- 
ságokkal leírható élethelyzetben lévő hallgatók (munkavállaló egyetemista, gyermekét nevelő nő, roma szakkollégista, kórustag, élsportoló stb.) egyetemi teljesítményének, a családi, vallásos és egyéb kulturális kötődések iskolai pályafutásban betöltött szerepének jelentőségét. A szocializációs minták közötti különbségek árnyalt megismerése remélhetőleg lehetőséget teremt az egyetemi tanárképzés által megkívánt (kulturális, felkészültségi) szintre lépés optimalizására. Újabban felbukkant e kutatói közösség részéről a perzisztencia kifejezés tudatos használata: ennek kapcsán azt vizsgálják, hogy milyen csoportsajátos törésvonalak mentén határozhatók meg az egyetemi hallgatók egyéni előrejutási stratégiáinak a típusai, jellemzői. A nemzetközi - főként oktatásszociológiai orientáltságú - szakirodalom eredményeinek felhasználásával az értékek óvása és a megmaradás különböző dimenziói válnak élettel telivé. A megmaradás igen jellemző szava volt Chrappán Magdolna előadásának. Oly módon is, hogy a diákok ne morzsolódjanak le, s oly módon is, hogy zömükben a régióban, a régió nagyon is markáns közegében maradva fogják leélni életüket. Továbbá a megmaradás ethosza lengi be az egész szakmai közösséget a Kárpát-medencei együttműködés jegyében, szellemében is.

A kívülállónak és a félig-meddig outsidernek egyaránt kínálná magát a lehetőség, hogy a szegedi tanárképző mühely munkáját az értékek méréséhez kapcsolja - ha már az érték fogalmát választottuk a négy bemutatkozó műhely közös értelmezési kategóriájául. Molnár Edit Katalin előadásának felületes hallgatója talán a referátum végén is megelégedett ezzel az olvasattal. Ugyanakkor a szegedi mühely valójában ennél lényegesen többet kínál. A bemeneti mérés, a kognitív készségek részletes feltárása, az abból táplálkozó visszacsatolás nem értelmezhető csupán értékmérésként (vagy értékbecslésként - hogy ki melyik „keménységü” fogalomban hisz inkább, az attól tartok, filozófiai és antropológiai jellegű kérdés). Hiszen a problémamegoldó gondolkodás fejlesztésével, a tantárgypedagógiai kutatás-fejlesztési aktivitásokkal, az akciókutatás paradigmájának előtérbe helyezésével, az egyéni pedagógiai fogalomértelmezésre fókuszálással a mérés-értékelésen messze túlmutató célok mentén írható le e szakmai közösség munkája. Még akkor is, ha a hatékonyságnövelés nehéz feladatnak tünik: a bemeneti - folyamatközi - kimeneti mérések egyik fontos tanulsága, hogy csak igen lassú változásokat lehet elérni a tanárjelölt (vagy nyilván bármilyen más szakos) hallgatónál. Erősek a személyes tapasztalatokon alapuló nézetek, amelyek korlátokként jelentkeznek a pedagógusképzésben, a tanári pálya markánsan új értelmezését adó paradigmák elfogadásában. Ezáltal viszont felértékelődik az intenzív reflexió, az in- 
duktív gondolkodás, s általában a rendszer különböző aktoraival való interakció. Abból kell kiindulni tehát, ami rendelkezésünkre áll - csak tegyük ezt minél tudatosabban, bármilyen minőségjavító lehetőséget azonnal felismerve és kihasználva. Ennek jegyében pedig már távolról sem értékmérésről, hanem az értékek hasznosításáról beszélhetünk.

Értékek gyarapitása, megújítása - talán így foglalható össze leginkább az ELTE PPK pedagógiai innovációk iránti elkötelezettsége. (A műhelyt a szimpóziumon Rapos Nóra képviselte.) A legkülönbözőbb külföldi és magyarországi fejlesztési aktivitások megismerése, feltárása, az ezt lehetővé tevő szakpolitikai feltételrendszer alapos elemzése azt a célt szolgálja, hogy a modern pedagógia oly magasan jegyzett ideái, mint az önszabályozó tanulás, a reflektivitás, az egyéni döntéshozatal és felelősségvállalás, a pedagógusok extramurális, szakmai alapon történő közösségi szerveződése mind több iskolában (és iskola holdudvarában) váljon valódi lehetőséggé, reális alternatívává. A megújulás ebben a felfogásban egyszerre rendszerszintű feltételekhez, egyéni nézőpontokhoz és magatartáshoz kötött kihívás. Ez a kettősség pedig a tanárképzésben dolgozókat is komplex probléma elé állítja: hiába kutatjuk az oktatás hazai és nemzetközi makrostruktúráit, ha nem figyelünk a pedagógus egyéni élethelyzetére, egyedi igényeire és mozgásterére. Ám önmagában a hallgatóra, az ő pedagógiai felkészültségének, attitűdjének alakítására való fókuszálás sem célravezető, hiszen bármilyen új gondolatot, hozzaállást is próbálunk közvetíteni felé, a pályakezdés után a munkahelyi környezet viszonyai gyorsan kiolthatják az egyetemen tanultak hatását. Ezért válik fontossá a kontextualizálás problémája: akár a strukturális reformok egyéni szintű értelmezéséről, akár az egyéni felkészültség környezeti feltételekkel való harmóniájáról beszélünk, mindenképpen egy egymást feltételező, egymástól függő, finom rendszerrel szembesülünk.

A négy tudományegyetemi tanárképző mủhely jellemző fogalomhasználata közötti tipikus különbségek számottevőek és rendkívül tanulságosak. Még a látszólag azonos vagy egymáshoz közeli kifejezések is markánsan más-más kontextusban jelentek meg az előadásokban: szinte ugyanazokkal a szavakkal fogalmazott meg épp ellentétes irányú mozgásokat Rapos Nóra és Chrappán Magdolna. Eszerint másfajta mintát, példát lehet mutatni az egyetemre mint elit intézménybe beiratkozó hallgatónak úgy is, hogy hátrányos helyzetű, a nagyvárosi közegtől távoli iskolákba, mikrovilágokba kalauzolják a tanárjelöltet, s úgy is, hogy az éppen hátrányos helyzetű mikrovilágokból érkező diákot vezetik be a kultúra maga- 
sabb régióiba. Hasonlóan szemléletes volt, ahogyan a szakmai közösség - klaszter - közösségi tanulás egymásra hasonlító kifejezések hangzása volt teljesen eltérő. Ezek az írásban nehezen vagy egyáltalán nem visszaadható parányi eltérések is tovább erősítik a cikk eleji felsorolás nyújtotta benyomást: négy határozott kontúrvonalak mentén tagolódó szellemi mủhelyről beszélhetünk.

Kérdés, hogy mit tehetünk e négy, egyenként rendkívül komoly szellemi gyökerekből táplálkozó, önmagában értékes és színvonalas iskolával. Kínálja magát a csábító lehetőség, hogy a többi tanárképző intézmény mintegy svédasztalként fogja föl ezt a szakmai kínálatot, s lehetőleg mindegyik alternatívának a vonzó elemeiből kiválogasson ezt-azt. (Nem állítható, hogy az előadásokat követő hozzászólásokban nem merült fel máris ez az opció.) Esetleg a négy szellemi közösség is eljátszik a gondolattal, hogy elles, kipróbál ezt-azt a társintézménytől. Ám épp azért, mert ezek az összeszokott iskolák ilyen szilárd alapokra épülnek, s mert mindegyikőjük összetett, sok-sok egymáshoz illő darabból álló szisztémát alakított ki, a svédasztalról válogatás nem tűnik kifizetődőnek. Sőt ellenkezőleg: a vonzó elemek kontextus nélküli átvételük, esetleg egymásra halmozásuk során jó eséllyel inflálódnak. Rosszabb esetben széles körben meg is győződnek arról a kollégák, hogy ami Szegeden / Pécsen / a „Kazyban” / Debrecenben müködött, az „nálunk nem múködik, mert teljesen mások, sokkal rosszabbak a viszonyok”. Az innováció halála a kontextusnélküliség - hallhattuk ki a tanulságot Rapos Nóra előadásából.

Így aztán a párhuzamosan fejlődő-alakuló értékvilágok másfajta közös hasznosításán kell gondolkodnunk. Az előadásokat hallva önkéntelenül is a „versengő alternatívák” kifejezés jutott eszembe. Nem a mühelyek versengenek egymással, nem kenyérharcról beszélek, hanem megközelítésekről, szellemiségekről, paradigmákról, amelyek egymástól határozottan eltérő modelleket eredményeznek. Ezek a modellek attól jók, hogy egyediek. Ez viszont nem jelenti azt, hogy helyenként és időnként nem kapcsolódhatnak egymáshoz, vagy nem termékenyíthetik meg és állíthatják enyhén módosuló pályára egymást. Az egymás mellett futó utak időnként keresztezhetik egymást kettesével, hármasával - akár négyesével is.

A kifejezés hallatán Pusztai Gabriella azt vetette fel, hogy nem versengésről, hanem valójában egymás kölcsönös kiegészítéséről van szó. A négy tudományegyetemi tanárképző múhely szinte hézagmentesen illeszkedik egymáshoz, s együtt adják ki egy puzzle összképét. Elismerem, a metafora érzékletes, s a magyarországi tanárképzés térképre, mentális térképre vetítését kifejezetten segíti. 
Ha visszagondolunk a szimpózium két órájára, valóban érezhetjük úgy, hogy a jelenkori magyarországi tanárképzés - csaknem teljes - tablója tárult a szemünk elé.

A tanárképzésben részt vevő hallgató viszont ezt nem érezheti (de még az országot csak kevéssé járó oktató sem). Ő egyetlen modellt fog megismerni, s a teljes tabló még a doktorandusz számára sem nyílik ki egészen. Nyilván nem fog senki mind a négy intézetben tanulni néhány évet, s láthatóan nincs egyelőre mód arra, hogy egyetlen intézmény tanárképzésében tanulva behatóan megismerje a másik három intézet szakmai ethoszát. Elképzelhető, hogy ez egyfajta végcélja legyen a négy tudományegyetemi tanárképzés közös szimpóziumával megindult (vagy általa csak megerősített) kommunikációnak? Végül is könnyen el tudnék képzelni egy olyan víziót, amelyben legalább a hazai alternatívák bemutatására minden tanárképző műhelyben sor kerül, de csak akkor, ha ezt megelőzi a versengő alternatívák létében rejlő legnagyobb lehetőség kihasználása. A négy nagy mühely bizonyosan mást és bizonyosan hiteleset tudna mondani olyan nagy kérdésekben, amelyek régóta gúzsba kötik a tanárképzés egészét. A kettes, hármas, négyes kereszteződések valóságos csomópontokká válhatnának egy intenzív, egyenrangú, kenyérharctól mentes, szakmai együttmúködésben. Közös téma, közös megoldandó feladat bőségesen adódna: mit kezdjünk a digitalizációval; mit kezdjünk a szigorú tantervi szabályozástól roskadozó, régen elavult tantárgyi struktúrával; mit kezdjünk a társadalom kettészakadásának iskolákra gyakorolt hatásával; miként igazodjanak leendő tanáraink az ökoszisztémánk fokozatos öszszeomlásakor ránk zúduló válsághelyzetekhez? Nyilván nem okozna nehézséget további feszítő kérdések megfogalmazása sem.

Téma, feladat tehát bőven van, s a magyarországi tanárképzés nemcsak rendelkezik rendkívül színvonalas tudásokkal is, hanem ezek a tudáselemek modellszerüen csoportosulva esélyt kínálnak az empatikus, komplex megközelítésekhez is. Feltéve, hogy az utak nem párhuzamosan futnak, s nem csak időnként, mintegy véletlenszerủen keresztezik egymást - hanem tudatosan kialakított csomópontokban is találkoznak. 